\title{
PENGGANTIAN TEPUNG IKAN DENGAN TEPUNG KEONG MAS PADA LEVEL BERBEDA DALAM RANSUM TERHADAP PERFORMANS DAN KARKAS ENTOK
}

\author{
TAMI, I W. ${ }^{1)}$, I M. MASTIKA ${ }^{2)}$, DAN I M. NURIYASA ${ }^{2)}$ \\ 1) Mahasiswa Program Studi Magister Peternakan Universitas Udayana \\ 2) Fakultas Peternakan Universitas Udayana, Denpasar Bali \\ e-mail: iwyntammy@yahoo.com
}

\begin{abstract}
ABSTRAK
Penelitian mengenai pengganti tepung ikan dengan tepung keong mas pada level berbeda dalam ransum terhadap performans dan karkas entok telah dilaksanakan. Rancangan yang digunakan dalam penelitian ini adalah rancangan acak kelompok (RAK), dengan lima perlakuan dan empat ulangan sehingga terdapat 20 unit percobaan. Perlakuan ransum yang diberikan adalah menggunakan $15 \%$ tepung ikan sebagai ransum kontrol (Ro), penggantian 25\% tepung ikan dengan tepung keong mas (R1), penggantian 50\% tepung ikan dengan tepung keong mas (R2), penggantian75\% tepung ikan dengan tepung keong mas $\left(\mathrm{R}_{3}\right)$ dan penggantian 100\% tepung ikan dengan tepung keong mas (R4). Ransum dan air minum diberikan secara adlibitum. Hasil penelitian tidak ada perbedaan yang nyata $(\mathrm{P}>0,05)$ pada kelima perlakuan terhadap performans dan karkas entok. Hasil penelitian juga menunjukan entok yang diberikan ransum penggantian tepung ikan 75\% dengan tepung keong mas ( 33 ) menghasilkan performans dan karkas paling tinggi. Berdasarkan hasil penelitian dapat disimpulkan bahwa penggantian tepung ikan dengan tepung keong mas sampai 100\% tidak mempengaruhi performans dan karkas entok, namun penggantian $75 \%$ tepung ikan dengan tepung keong mas menghasilkan performans dan karkas paling tinggi.
\end{abstract}

Kata kunci: keong mas, entok, performans, karkas

\section{EFFECT OF REPLACEMENT OF FISH MEAL BY GOLDEN SNAIL MEAL AT DIFFERENT LEVEL IN THE DIET ON THE PERFORMANCE AND CARCASS OF MUSCOVY DUCKS}

\begin{abstract}
An experiment was conducted on the replacement of fish meal with golden snails meal at different level on performance and carcass of muscovy ducks. A randomized complete block design (RCBD), with five treatments and four replications was used in this study so in other words there were 20 experiments unit conducted. Muscovy ducks were given diet using $15 \%$ fish meal as a control diet (Ro), the replacement of $25 \%$ fish meal with golden snails meal (R1), the replacement of 50\% fish meal with golden snails meal (R2), replacement $75 \%$ fish meal with golden snails meal $\left(\mathrm{R}_{3}\right)$ and $100 \%$ replacement of fish meal with golden snails meal (R4). Meal Rations and drinking water are provided adlibitum. The results of the experiment showed that there was no significant difference $(\mathrm{P}>0.05)$ among in five treatments on the performances and carcass of muscovy ducks. The results also showed Muscovy duck given diet 75\% replacement of fish meal with golden snails meal (R3) produced the highest performance and carcass. Based on the results of this experiment it was concluded that the replacement of fish meal with golden snails meal up to $100 \%$ did not affect performance and carcass of muscovy ducks.
\end{abstract}

Keywords: golden snails, muscovy ducks, performance, carcass

\section{PENDAHULUAN}

Entok merupakan salah satu ternak alternatif yang mempunyai potensi besar untuk diversifikasi penyediaan sumber protein hewani karena mudah dalam pemeliharaan, lebih tahan terhadap penyakit dan dapat memanfaatkan hijauan dan limbah pertanian untuk pakannya (Setioko et al., 2002). Penyebaran ternak entok di Indonesia cukup luas karena diharapkan mampu membantu dalam pemenuhan kebutuhan protein hewani. Kelebihan dari entok yaitu lebih tahan terhadap penyakit dan merupakan jenis unggas sebagai penghasil daging. Entok memiliki bobot badan cukup tinggi, rata-rata entok jantan memiliki bobot badan 3 
$\mathrm{kg}$ /ekor sedangkan betina $1,3 \mathrm{~kg} /$ ekor (Johnson dan Hawk, 2009; Petty, 2011). Disamping itu, entok menjadi pilihan untuk dibudidayakan karena di Bali populasinya masih rendah yaitu sebanyak 38.215 ekor dan populasi terbanyak di Kabupaten Jembrana sebanyak 7.658 ekor (Disnakkeswan 2015).

Produktivitas entok umumnya agak lambat karena cara pemeliharaannya yang kurang baik. Salah satu upaya peningkatan produktivitasnya dapat ditempuh melalui cara pemeliharaan dengan sistem intensif, tetapi kendalanya adalah biaya pakan terutama bahan pakan sumber protein masih mahal seperti kedelai dan tepung ikan. Upaya menekan biaya produksi yaitu mengoptimalkan daya guna bahan pakan lokal yang terdapat di daerah tertentu, sehingga biaya pakan dapat ditekan tanpa mengganggu produktivitas ternak (Satata, 1992). Salah satu bahan pakan lokal yang tidak bersaing dengan manusia, harganya murah, serta mengandung nutrien yang baik seperti keong mas dapat dipakai sebagai pengganti tepung ikan dalam ransum ternak entok.

Keong mas merupakan hama tanaman padi sejak berumur 10 (sepuluh) hari setelah pindah tanam. Kerugian dari serangan keong mas yaitu menurunkan produksi gabah berkisar $16-40 \%$. Keong mas sangat potensial untuk bahan campuran pakan entok sebagai pengganti tepung ikan. Kandungan nutrien tepung keong mas adalah protein kasar (PK) 46,2\%, energi termetabolis (ME) $1920 \mathrm{kkal} / \mathrm{kg}$, kalsium (Ca) 2,98\%, dan fosfor (P) 0,35\%. Lebih lanjut dijelaskan bahwa pemberian tepung keong mas sebesar 9\% dalam ransum tidak berpengaruh nyata terhadap kualitas telur itik (Purnamaningsih, 2010). Menurut Sulistiono (2007), pemberian tepung keong mas sebanyak $10 \%$ dalam ransum itik mampu meningkatkan laju pertumbuhan dan produksi telur hingga 80\% dan mampu mengimbangi penggunaan tepung ikan. Melihat permasalahan tersebut maka penelitian penggunaan keong mas sebagai pengganti tepung ikan pada ransum entok perlu dilaksanakan untuk mengetahui pengaruhnya terhadap performans dan karkas entok.

\section{MATERI DAN METODE}

\section{Entok}

Entok yang digunakan dalam penelitian ini adalah entok jantan lokal dengan rata-rata bobot badan 959,9 gr $\pm 84,1$ gr yang dilakukan di Desa Gulingan untuk pemeliharaan dan pemotongan yang berlangsung selama 60 hari.

\section{Kandang}

Kandang yang dipergunakan sebanyak 20 petak kandang berukuran panjang $50 \mathrm{~cm}$, lebar $70 \mathrm{~cm}$, tinggi
$50 \mathrm{~cm}$ dan alas kandang terbuat dari kawat dengan jarak dari lantai kandang $50 \mathrm{~cm}$ untuk dua ekor entok. Setiap petak kandang dilengkapi dengan tempat ransum dan tempat air minum.

\section{Ransum dan Air Minum}

Ransum diberikan pada ternak dalam bentuk tepung adalah iso protein dan energi dengan kandungan protein kasar $16 \%$ dan energi termetabolis $2.900 \mathrm{kkal} /$ kg (NRC,1994), terdiri dari 5 formula ransum sesuai dengan rencana perlakuan. Pemberian ransum secara ad libitum diberikan dua kali sehari yaitu pada pagi hari pukul 06.30 Wita dan pada sore hari pukul 17.00 Wita, pemberian air minum juga diberikan secara ad libitum

\section{Variabel yang diamati}

Variabel performans yang diamati dalam penelitian ini meliputi: bobot badan akhir, pertambahan bobot badan harian, konsumsi ransum dan konversi ransum. Bobot badan akhir didapatkan dari penimbangan bobot entok pada akhir penelitian.

Data karkas diperoleh dengan cara memotong ternak entok pada akhir penelitian. Ternak yang akan dipotong terlebih dahulu dipuasakan selama 12 jam, tetapi air minum tetap diberikan. Pemotongan ternak akan dilakukan berdasarkan cara USDA (Unaited State Departement of Agriculture,1977) yaitu dengan memotong vena jugularis dan arteri carotis yang terletak antara tulang kepala dengan ruas tulang leher pertama. Pemisahan bagian tubuh entok, yaitu dengan pengeluaran saluran pencernaan, organ dalam, pemotongan kaki serta kepala hingga diperoleh karkas (USDA, 1985).

\section{Analisis Statistik}

Penelitian menggunakan rancangan acak kelompok (RAK) dengan lima perlakuan pakan. Masing-masing perlakuan diulang sebanyak delapan (8) kali sehingga terdapat 40 unit percobaan. Perlakuan pakan yang diberikan adalah ransum yang menggunakan $15 \%$ tepung ikan dalam ransum sebagai ransum kontrol (Ro), penggantian 25\% tepung ikan dengan tepung keong mas dalam ransum (R1), penggantian50\% tepung ikan dengan tepung keong mas dalam ransum (R2), penggantian $75 \%$ tepung ikan dengan tepung keong mas dalam ransum (R3) dan penggantian100\% tepung ikan dengan tepung keong mas dalam ransum (R4).

Data yang diperoleh ditabulasi dan pengolahan data dilakukan dengan sidik ragam untuk mengetahui pengaruh perlakuan yang diberikan apabila berbeda nyata $(\mathrm{P}<0,05)$, kemudian dilanjutkan dengan uji Duncan's Multiple Range Test (Steel dan Torrie, 1980). 


\section{HASIL DAN PEMBAHASAN}

Hasil penelitian menunjukkan bahwa entok yang mendapatkan perlakuan ransum $\mathrm{R}_{3}$ menghasilkan bobot badan akhir paling tinggi yaitu 2580,oo g, namun tidak menunjukkan perbedaan yang nyata $(\mathrm{P}>0,05)$ dengan Ro, R1, R2 dan R4 yang masing-masing 2578,75 g, 2560,o0 g, 2564,00 g dan 2470,63 g. Hal yang sama dihasilkan pada pertambahan bobot badan harian secara statistik tidak menunjukkan perbedaan nyata $(\mathrm{P}>0,05)$ tersaji pada Tabel 1 . Hal ini disebabkan karena kandungan nutrien ransum hampir sama dan ransum yang dikonsumsi hampir sama pada kelima perlakuan, sehingga jumlah zat-zat makanan yang dikonsumsi juga hampir sama. Hasil ini sejalan dengan pendapat Soeharsono (1976) bahwa konsumsi ransum mempunyai implikasi terhadap konsumsi zat-zat makanan yang lainnya dan akan berpengaruh terhadap laju pertumbuhan yang dimanifestasikan dalam bobot badan akhir dan pertambahan bobot badan. Bobot badan akhir dan pertambahan bobot badan harian pada entok yang mendapat perlakuan $\mathrm{R}_{3}$ lebih tinggi dari perlakuan lainnya disebabkan karena entok yang diberikan perlakuan $\mathrm{R}_{3}$ mengkonsumsi ransum paling tinggi. Bobot badan akhir dan pertambahan bobot badan entok dipengaruhi oleh jumlah pakan yang dikonsumsi dan nutrien yang diserap dalam tubuh entok.

Menurut Rasyaf (1995) pada ransum isoenergi dan isoprotein, konsumsi ransum yang lebih tinggi mengindikasikan bahwa nutrien yang diserap lebih banyak oleh tubuh entok akan memberikan bobot badan akhir dan pertambahan bobot yang lebih tinggi, hal ini dikarenakan perkembangan jaringan tubuh dan lemak akan banyak dapat dilakukan oleh ternak. Konsumsi ransum yang lebih tinggi pada perlakuan R3 juga akan mengakibatkan meningkatnya konsumsi energi dan protein yang merupakan komponen utama dalam menyusun komponen tubuh ternak entok. Hasil penelitian sejalan dengan pendapat yang dikemukakan
Xiangmei (2008) yang menyatakan imbangan energi dan protein sangat penting diperhatikan untuk mencapai produktivitas optimal ternak.

Menurut Sulistiono (2007), pemberian tepung keong mas sebanyak 10\% dalam ransum itik mampu meningkatkan laju pertumbuhan dan produksi telur hingga $80 \%$ dan mampu mengimbangi penggunaan tepung ikan. Selanjutnya Harmentis et al. (1998) melaporkan bahwa penggunaan tepung keong mas dalam ransum ayam broiler dianjurkan sebanyak $4 \%$.

Secara statistik rataan konsumsi ransum pada kelima perlakuan Ro, R1, R2, R3 dan R4 masing-masing 100,93 $\mathrm{g} / \mathrm{hari}, 100,65 \mathrm{~g} / \mathrm{hari}, 100,83 \mathrm{~g} / \mathrm{hari}, 101,00 \mathrm{~g} / \mathrm{hari}$ dan 98,34 g/hari (Tabel 1), dimana diantara perlakuan tidak berbeda nyata $(\mathrm{P}>0,05)$. Hal ini disebabkan ransum pada kelima perlakuan disusun isoprotein dan isoenergi. Tingkat energi dalam ransum berpengaruh terhadap konsumsi ransum. Tingkat energi pada kelima ransum perlakuan adalah sama, yaitu berkisar pada 2900 $\mathrm{kkal} / \mathrm{kg}$, dengan demikian sesuai dengan pernyataan tersebut, mengakibatkan kelima ransum perlakuan dikonsumsi oleh entok dalam jumlah yang relatif sama. Sesuai dengan pendapat Parakkasi (1999), tingkat konsumsi dipengaruhi oleh beberapa faktor antara lain jenis kelamin, umur, bangsa ternak, dan kualitas nutrien pakan terutama kandungan energi dan protein kasar. Faktor-faktor yang mempengaruhi konsumsi ransum adalah selain kandungan energi ransum adalah tipe ternak, temperatur dan iklim setempat, bobot badan, dan serat kasar ransum (Scott et al., 1982; Wahju,1997).

Entok yang mendapat perlakuan R3 mempunyai konversi ransum paling rendah yaitu 3,70 tidak berbeda nyata $(\mathrm{P}>0,05)$ dari Ro $(3,84), \mathrm{R} 1(3,79)$, R2 $(3,81)$ dan R4 (3,92) seperti pada Tabel 1. Rataan konversi ransum dalam penelitian yang belum berpengaruh pada semua perlakuan ada hubungannya dengan konsumsi pakan dan pertambahan bobot badan yang tidak berbeda nyata. Hal ini juga disebabkan ransum yang diberikan seimbang antara protein dan energinya

Tabel 1. Performans entok yang diberikan ransum dengan level tepung keong mas berbeda sebagai pengganti tepung ikan

\begin{tabular}{|c|c|c|c|c|c|c|}
\hline \multirow{2}{*}{ Variabel } & \multicolumn{6}{|c|}{ Perlakuan ${ }^{1)}$} \\
\hline & RO & R1 & R2 & R3 & R4 & SEM $^{3)}$ \\
\hline Berat badan awal (g) & $958,75^{\mathrm{a} 2)}$ & $959,50^{a}$ & $965,25^{a}$ & $957,75^{a}$ & $958,25^{a}$ & 7,29 \\
\hline Berat badan akhir (g) & $2578,75^{a}$ & $2560,00^{\mathrm{a}}$ & $2564,00^{a}$ & $2580,00^{a}$ & $2470,63^{a}$ & 21,35 \\
\hline Pertambahan berat badan $(\mathrm{g} / \mathrm{hr})$ & $26,60^{\mathrm{a}}$ & $26,72^{\mathrm{a}}$ & $26,81^{a}$ & $27,50^{\mathrm{a}}$ & $25,34^{\mathrm{a}}$ & 0,38 \\
\hline Konsumsi ransum $(\mathrm{g} / \mathrm{hr})$ & $100,93^{a}$ & $100,65^{a}$ & $100,83^{a}$ & $101.00^{\mathrm{a}}$ & $98,34^{a}$ & 0,48 \\
\hline Konversi ransum & $3,84^{\mathrm{a}}$ & $3,79^{\mathrm{a}}$ & $3,81^{\mathrm{a}}$ & $3,70^{\mathrm{a}}$ & $3,92^{\mathrm{a}}$ & 0,05 \\
\hline
\end{tabular}


Tabel 2. Karkas entok yang diberikan ransum dengan level tepung keong mas berbeda sebagai pengganti tepung ikan

\begin{tabular}{|c|c|c|c|c|c|c|}
\hline \multirow{2}{*}{ Variabel } & \multicolumn{6}{|c|}{ Perlakuan ${ }^{1)}$} \\
\hline & RO & R1 & R2 & R3 & R4 & $\mathrm{SEM}^{3)}$ \\
\hline Bobot potong (g) & $2573,75^{\mathrm{a} 2)}$ & $2555,00^{a}$ & $2559,00^{a}$ & $2575,00^{a}$ & $2466,25^{a}$ & 21,39 \\
\hline Bobot karkas (g) & $1483,50^{\mathrm{a}}$ & $1393,25^{a}$ & $1416,00^{\mathrm{a}}$ & $1500,75^{a}$ & $1367,00^{\mathrm{a}}$ & 12,44 \\
\hline Persentase karkas (\%) & $57,77^{a}$ & $54,58^{a}$ & $55,40^{\mathrm{a}}$ & $58,34^{\mathrm{a}}$ & $55,64^{a}$ & 0,46 \\
\hline Daging karkas (\%) & $62,90^{\mathrm{a}}$ & $62,07^{a}$ & $62,59^{a}$ & $63,23^{a}$ & $61,41^{a}$ & 0,61 \\
\hline Tulang karkas (\%) & $30,44^{\mathrm{a}}$ & $31,18^{\mathrm{a}}$ & $30,88^{a}$ & $30,40^{\mathrm{a}}$ & $31,23^{a}$ & 0,81 \\
\hline Kulit karkas (\%) & $6,68^{a}$ & $6,67^{a}$ & $6,59^{a}$ & $6,35^{a}$ & $7,67^{a}$ & 0,07 \\
\hline Rasio daging dengan tulang karkas (\%) & $2,15^{a}$ & $2,11^{\mathrm{a}}$ & $2,13^{\mathrm{a}}$ & $2,18^{\mathrm{a}}$ & $2,03^{a}$ & 0,08 \\
\hline
\end{tabular}

Keterangan:

RO: Penggunaan $15 \%$ tepung ikan dalam ransum sebagai ransum kontrol

R1: Penggantian $25 \%$ tepung ikan dengan keong mas dalam ransum

R2: Penggantian $50 \%$ tepung ikan dengan keong mas dalam ransum

R3: Penggantian $75 \%$ tepung ikan dengan keong mas dalam ransum

R4: Penggantian $100 \%$ tepung ikan dengan keong mas dalam ransum

Superskrip yang sama pada baris yang sama menunjukan perbedaan yang tidak nyata $(P>0,05)$ dan superskrip berbeda pada baris yang sama menunjukan perbedaan yang nyata $(P<0,05)$ SEM: Standard Error of the Treatment Means

serta entok dalam penelitian efesien merubah pakan menjadi daging. Menurut Kamal (1997) dan Zuprizal (1993), besar kecilnya nilai konversi pakan dipengaruhi oleh kualitas pakan dan kemampuan ternak untuk mengubah pakan menjadi daging, keseimbangan pakan, ukuran tubuh, temperatur lingkungan, bobot hidup, bentuk fisik pakan, strain dan jenis kelamin. Konversi ransum entok yang diberikan perlakuan $\mathrm{R}_{3}$ ternyata lebih efisien dari perlakuan lainnya karena entok yang mendapat perlakuan $\mathrm{R}_{3}$ mengkonsumsi ransum yang dapat mengimbangi peningkatan pertambahan bobot badan yang lebih tinggi sehingga akhirnya dapat menghasilkan konversi ransum lebih baik.

Selanjutnya konversi ransum entok yang diberikan perlakuan R4 paling tinggi disebabkan ransum yang dikonsumsi tidak diimbangi dengan pertambahan bobot badannya dan berdasarkan hasil analisa proksimat ransum R4 kandungan proteinnya paling rendah sehingga didapat suatu nilai konversi ransum yang lebih tinggi atau efesiensi penggunaan nutrien rendah. Pernyataan tersebut sesuai dengan pendapat Sibbald et al. (1960) bahwa konversi ransum meningkat dengan meningkatnya konsumsi ransum dan pertambahan bobot badan. Bila dilihat dari besarnya konversi ransum yang diperoleh pada entok yang diberikan ransum sampai pada level $75 \%$ tepung keong mas sebagai pengganti tepung ikan dalam ransum masih dalam batas yang wajar. Ini sesuai dengan yang dikemukakan Harahap (1993) bahwa konversi ransum entok adalah 3,79 atau $35,98 \%$ lebih rendah dari itik.

Hasil penelitian terhadap rataan bobot potong, bobot karkas dan persentase karkas entok akibat pemberian ransum dengan level tepung keong mas sebagai pengganti tepung ikan berbeda tersaji pada Tabel 2. Rataan bobot potong entok pada perlakuan $\mathrm{R}_{3}$ (2575,00 g) paling tinggi diantara kelima perlakuan, sedangkan perlakuan ransum Ro, R1, R2 dan R4 masing-masing 0,05\%, 0,78\%, o,62\% dan 4,22\% lebih rendah daripada perlakuan ransum $\mathrm{R}_{3}$, secara statsitik berbeda tidak nyata $(\mathrm{P}>0,05)$. Perbedaan yang tidak nyata pada hasil penelitian ini disebabkan oleh bobot badan akhir yang dicapai selama pertumbuhan pada kelima perlakuan yang tidak menunjukkan perbedaan nyata. Hal ini sesuai dengan pernyataan Nasroedin (1995) dan Zuprizal (1998) bahwa bobot badan akhir yang dicapai selama pemeliharaan dengan komposisi pakan berbeda atau sama, akan berdampak kepada bobot potong yang dihasilkan.

Pendapat yang sama dikemukakan Rasyaf (1995) bahwa bobot badan akhir salah satunya dapat menentukan bobot potong, apabila ternak sudah disembelih. Bobot potong paling tinggi entok pada perlakuan R3 disebabkan karena perlakuan R3 mengkonsumsi ransum paling tinggi. Konsumsi ransum yang tinggi pada ransum isoprotein dan isoenergi akan mengakibatkan nutrien yang diserap oleh tubuh entok menjadi tinggi sehingga bobot badan akhir dan pertumbuhan juga tinggi. Konsumsi protein dan energi yang lebih tinggi akan menghasilkan laju pertumbuhan yang lebih cepat (Soeparno, 2005). Hal ini berkorelasi positif terhadap bobot karkas dan persentase karkas. Selain itu entok yang mendapatkan perlakuan R3 paling efesien menggunakan ransum yang diindikasikan oleh nilai konversi ransum yang paling rendah (Tabel 1).

Karkas merupakan organ tubuh yang masak lambat, sehingga dengan bertambahnya umur, pertumbuhannya semakin bertambah dan persentase terhadap bobot potong juga meningkat. Rataan bobot karkas entok paling tinggi terjadi pada perlakuan ransum $\mathrm{R}_{3}$ (1.500,75 g), sedangkan perlakuan ransum Ro, R1, R2, dan R4 masing-masing 1,15\%, 7,16\%, 5,65\% dan 8,91\% lebih rendah daripada perlakuan ransum $\mathrm{R}_{3}$. Hal yang sama ditunjukkan terhadap variabel persentase karkas paling tinggi dihasilkan pada perlakuan $\mathrm{R}_{3}(58,34 \%)$ yang lebih tinggi dari perlakuan Ro, R1, R2 dan R4, masing-masing sebesar 57,77\%, 54,58\%, 55,40\% dan 
55,64\% (Tabel 2). Secara statistik bobot karkas dan persentase karkas tidak berbeda nyata $(\mathrm{P}>0,05)$. Hal ini dikarenakan bobot potong dari kelima perlakuan tidak menunjukan perbedaan yang nyata sehingga bobot dan persentase karkas tidak berbeda nyata. Produksi karkas tercermin dari komponen daging, lemak, dan tulang entok yang sangat dipengaruhi oleh bobot potongnya Soeparno (2005). Resnawati dan Hardjosworo (1976) menyatakan bahwa persentase karkas berbanding lurus dengan bobot badan atau semakin meningkat bobot badan cenderung menghasilkan persentase karkas yang tinggi pula.

Hasil penelitian terhadap komposisi fisik karkas entok (daging, kulit dan tulang) pada Tabel 2 secara statistik tidak menunjukan perbedaan yang nyata $(\mathrm{P}>0,05)$. Rataan persentase daging karkas entok yang mendapat perlakuan ransum $\mathrm{R} 3$ paling tinggi $(63,23 \%)$, sedangkan perlakuan ransum Ro, R1, R2 dan R4 masing-masing 62,90\%, 62,07\%, 62,59\%, dan 61,41\% lebih rendah daripada perlakuan $\mathrm{R}_{3}$. Hal ini disebabkan entok pada penelitian ini pada saat dipotong memiliki umur yang sama sehingga persentase komposisi fisik karkas yang dihasilkan tidak menunjukan perbedaan yang nyata. Menurut Cunningham dan Acker (2001) bahwa umur ternak yang muda akan menghasilkan persentase daging dan tulang relatif tinggi dan persentase lemak rendah, dan sebaliknya pada umur yang lebih tua persentase daging dan tulang akan rendah sedangkan persentase lemak akan relatif lebih tinggi. Selain itu selama pertumbuhan, tulang tumbuh secara terus-menerus dengan laju pertumbuhan relatif lambat dan cenderung menurun seiring meningkatnya umur (Soeparno 2005). Rihi (2004) menyatakan peningkatan persentase karkas yang dihasilkan relatif rendah akan memberikan pengaruh yang tidak nyata terhadap persentase daging dan tulang karkasnya.

Hasil penelitian ditunjukkan pada Tabel 2, bahwa rasio daging dengan tulang entok perlakuan R3adalah 2,18\%, yang lebih tinggi 1,38\%, 3,24\%, 2,34\% dan 7,09\% dari perlakuan Ro, R1, R2 dan R4.Secara statistik tidak berbeda nyata $(\mathrm{P}>0,05)$. Hal ini disebabkan hasil persentase bobot daging dan bobot tulang pada kelima perlakuan tidak menunjukan perbedaan nyata. Selain itu umur entok yang relatif sama juga akan menghasilkan rasio antara daging dan tulang yang tidak berbeda nyata. Aberle et al. (2001) menyatakan bahwa semakin tinggi nilai rasio daging dengan tulang menunjukkan bahwa kualitas karkas semakin baik, karena nilai rasio daging dengan tulang dapat menggambarkan tinggi rendahnya hasil daging dan tulang dari karkas. Rasio daging dengan tulang yang tinggi menunjukkan bahwa hasil daging dari karkas lebih tinggi.

\section{SIMPULAN}

Berdasarkan hasil penelitian dapat disimpulkan bahwa penggantian tepung ikan dengan tepung keong mas sampai $100 \%$ tidak mempengaruhi performans dan karkas entok, namun penggantian $75 \%$ tepung ikan dengan tepung keong mas menghasilkan performans dan karkas cenderung lebih tinggi.

\section{UCAPAN TERIMAKASIH}

Pada kesempatan ini kami mengucapkan banyak terimakasih kepada Rektor Universitas Udayana, Dekan Fakultas Peternakan Universitas Udayana dan Ketua Progran Studi Magister Ilmu Peternakan Program Pasca Sarjana Universitas Udayana atas pelayanan administrasi, fasilitas pendidikan dan penelitian yang diberikan kepada penulis selama menjalani perkulihaan.

\section{DAFTAR PUSTAKA}

Aberle, E. D., C. J. Forest, H.B. Hedrick, M. D. Judge dan R. A. Merkel. 2001. The Principle of Meat Science. W.H. Freeman and Co. San Fransisco.

Anggraeni. 1999. Pertumbuhan Alometri dan Tinjauan Morfologi Serabut Otot Dada (Muscullus Pectoralis dan Muscullus Supracoracoracorideus) Pada Itik Dan Entok Lokal. Disertasi. Program Pasca Sarjana Institut Pertanian Bogor. Bogor.

Cunningham, M., and D. Acker. 2001. Animal Science and Industry. $6^{\text {th }}$ edition. Prentice Hall. New Jersey.

Dinas Peternakan dan Kesehatan Hewan Provinsi Bali. 2014. Informasi Data Peternakan di Provinsi Bali.

Harahap D. 1993.Potensi Itik Mandalung sebagai Penghasil Daging Ditinjau dari Berat Karkas dan Penilaian Organoleptik Dagingnya Dibandingkan dengan Tetuanya. Disertasi. Program Pascasarjana, Fakultas Peternakan, Institut Pertanian Bogor.

Harmentis, Y. Martinda, dan Nuraini. 1998. Pengaruh pemberian tepung daging keong mas (Pomacea canadiculata) yang diolah dengan batu kapur dalam ransum terhadap performa ayam broiler. J. Peternakan dan Lingkungan 4:20-25.

Johnson, S. A. and M. Hawk. 2009. Florida's Introduced Birds: Muscovy Duck (Cairina moschata). Department of Wildlife Ecology and Conservation, University of Florida/IFAS, Florida.

Kamal, M., 1994. Nutrisi Ternak I. Fakultas Peternakan, Universitas Gadjah Mada, Yogyakarta.

Nasroedin, 1995. Ilmu Produksi Ternak Unggas. Fakultas Peternakan Universitas Gadjah Mada Yogyakarta.

National Research Council. 1994. Nutrient Requirement of Poultry. Ninth Revised Edition. Printing and Publishing National Academy of Science. Washington. 
Parakkasi, A., 1999. Ilmu Nutrisi dan Makanan Ternak Ruminansia. UI Press. Jakarta.

Petty, C. 2011. Cairina moschata (Wild Muscovy duck). The Online Guide to the Animals of Trinidad and Tobago.

Purnamaningsih. 2010. Pengaruh Penambahan Tepung Keong Mas (Pomaceacanaliculata Lamarck) dalam Ransum Terhadap Kualitas Telur Itik. Skripsi.Fakultas Pertanian Universitas Sebelas Maret Surakarta.

Rasyaf, M, 1995. Pengelolah Usaha Peternakan Ayam Pedaging. PT. Gramedia Pustaka Utama, Jakarta. 2002. Manajemen Peternakan Ayam Broiler. Penebar Swadaya. Jakarta.

Resnawati, H. dan P. Hardjosworo.1976. Pengaruh Umur terhadap Persentase Karkas dan Efisiensi Ekonomis pada Ayam Broiler Unsexed. Lembaran LPP IV.

Rihi, J.L. 2004. Produksi karkas dan kualitas fisik daging kelinci lokal yang diberi kosentrat dengan level protein berbeda. Buletin Peternakan 28 (2): 65-71.

Satata, B. 1992. Pengaruh aras protein dan imbangan kombinasi lisin dan metionin pada ransum petelur tanpa dan dengan tepung ikan. Tesis. Program Pasca Sarjana. Universitas Gadjah Mada, Yogyakarta.

Scott, M. L., M. C. Nesheim and R. J. Young. 1982. Nutrition of Chicken. Third Edition. Ithaca, New York: M. L. Scott and Associates. 598.

Setioko, A. R., L. H. Prasetyo, B. Brahmantiyo dan M. Purba. 2002. Koleksi dan Karakterisasi Sifat-Sifat Beberapa Jenis Itik. Kumpulan Hasil-hasil Penelitian APBN Tahun Anggaran 2001. Balai Penelitian Ternak Ciawi, Bogor.
Sibbald, L. R., S. J. Slinger and Ashton. 1960. The influence of dietary calorie: protein ration on the weight gain and feed eficiency of growing chicks. Poultry Sci. 40: 308: 312.

Soeharsono.1976. Respon broiler terhadap beberapa kondisi lingkungan. Disertasi. Universitas Padjajaran Bandung.Bandung.

Soeparno. 2005. Ilmu dan Teknologi Daging. Cetakan ke-4. Gadjah Mada University Press, Yogyakarta.

Sulistiono.2007. Pengelolaan Keong Mas (Pomacea canaliculata). Prosiding. Konferensi Sains Kelautan dan Perikanan Indonesia I. Kampus FPIK, IPBDramaga, 17-18 Juli 2007: 124-136.

United States Department of Agriculture (USDA). 1977. Poultry Guiding Manual. U.S. Goverment Printing Office Washington D.C.

United States Department of Agriculture (USDA). 1985. Nutrient Database for Standard Reference RI.

Wahju, J. 1997. Ilmu Nutrisi Ternak. Gajah Mada University Press, Yogyakarta.

Xiangmei, G. 2008. Rabbit Feed Nutrition Study for Intensive, Large-Scale Meat Rabbit Breeding Qingdao Kangda Food Company Limited, China. http://www. mekarn.org/prorab/guan.htm. Disintir tanggal 18 Nopember 2010.

Zuprizal. 1993. Pengaruh Penggunaan Pakan Tinggi Protein terhadap Penampilan, Karkas dan Pelemakan Ayam Pedaging Fase Akhir. Buletin Peternakan. Vol. 17:110-118. 